\title{
Getting Started in Elementary School: Cognitive Competence, Social Skills, Behavior, and Stress
}

\author{
Marta Regina Gonçalves Correia-Zanini - Universidade de São Paulo, Ribeirão Preto, Brasil \\ Edna Maria Marturano - Universidade de São Paulo, Ribeirão Preto, Brasil
}

\begin{abstract}
The entry into elementary education - EE - represents an important transition in child development. The study aimed to assess stability and change in indicators of academic achievement, general intelligence, social skills, behavioral adjustment, and stress between the $1^{\text {st }}, 2^{\text {nd }}$ and ${ }^{3 r d}$ year of EE. The participants were 151 children (79 boys), longitudinally evaluated using the Social Skills Rating System, Raven's Progressive Matrices, Provinha Brazil, Child Stress Scale and the School Stressors Inventory. The results indicated at least moderate stability of the variables and a continuous increase in academic achievement. Girls showed better indicators of social skills and behavioral adjustment. Children showed more externalizing behaviors in the $1^{\text {st }}$ year; more stress symptoms in the $2^{\text {nd }}$ year; greater general intelligence, more academic social skills and fewer stress symptoms in the $3^{\text {rd }}$ year. These trends suggest that the transition extends up to $2^{\text {nd }}$ year, whereas developmental achievements are consolidated in the $3^{\text {rd }}$ year.

Keywords: elementary education, school transition, longitudinal, child development, adjustment
\end{abstract}

\section{Primeiros Passos no Ensino Fundamental: Competência Cognitiva,} Habilidades Sociais, Comportamento e Estresse

\begin{abstract}
Resumo
O ingresso no ensino fundamental - EF sinaliza importante transição no desenvolvimento da criança. O objetivo do estudo foi verificar estabilidade e mudança em indicadores de desempenho acadêmico, inteligência geral, habilidades sociais, ajustamento comportamental e estresse entre o $1^{\circ}$, o $2^{\circ}$ e o $3^{\circ}$ ano do EF. Participaram 151 crianças ( 79 meninos), avaliadas longitudinalmente com o Social Skills Rating System, Matrizes Progressivas de Raven, Provinha Brasil, Escala de Stress Infantil e Inventário de Estressores Escolares. Os resultados indicaram estabilidade pelo menos moderada das variáveis e aumento contínuo no desempenho acadêmico. Meninas apresentaram melhores indicadores de habilidades sociais e ajustamento comportamental. As crianças mostraram mais comportamentos externalizantes no $1^{\circ}$ ano; mais sintomas de estresse no $2^{\circ}$ ano; maior inteligência geral, mais habilidades sociais acadêmicas e menos sintomas de estresse no $3^{\circ}$ ano. As tendências observadas sugerem que a transição se estende até o $2^{\circ}$ e as conquistas desenvolvimentais se consolidam no $3^{\circ}$ ano.

Palavras-chave: ensino fundamental, transição escolar, longitudinal, desenvolvimento infantil, ajustamento
\end{abstract}

\section{Primeros pasos en la Enseñanza Primaria: Competencia Cognitiva, Habilidades Sociales, Comportamiento y Estrés}

\begin{abstract}
Resumen
El ingreso a enseñanza primaria - EP indica una importante transición en el desarrollo de los niños. El propósito del estudio fue verificar la estabilidad y el cambio en indicadores del desempeño académico, inteligencia general, habilidades sociales, ajuste de comportamiento y estrés entre el primer y el tercer año de la EP. Participaron 151 niños (79 varones y 72 niñas), evaluados longitudinalmente con el Social Skills Rating System, Matrices Progresivas de Raven, Provinha Brasil, Escala de Estrés Infantil e Inventario de Estressores Escolares. Los resultados indicaron estabilidad moderada de las variables y aumento continuo en el desempeño académico. Las niñas mostraron mejores indicadores de habilidades sociales y ajuste de comportamiento. Los encuestados mostraron mayores comportamientos de exteriorización en el primer año; más síntomas de estrés en el segundo; y en el tercer año mayor inteligencia general, más habilidades sociales académicas y menos síntomas de estrés. Las tendencias observadas sugieren que la transición se extienda hasta el segundo año y las conquistas de desarrollo se consolidan en el tercer año.

Palabras clave: enseñanza primaria, transición escolar, longitudinal, desarrollo infantil, ajuste
\end{abstract}

Children spend much of their lives in school and that fact alone makes the school the most important context of development outside the family environment during the childhood years. At school children make friends, diversify their experiences, broaden their horizons in contact with diversity and exercise skills considered relevant for access to the adult world. It is also there that, in this intensive process of socialization and acculturation, they face daily demands to challenge their ability to solve problems.

Given the exposure to such diverse experiences, the years of elementary education (EE) are expected to be a period of important developmental conquests. In the cognitive domain, the expansion of academic skills can be considered normative (Gardinal-Pizato, Marturano, \& Fontaine, 2012; Matthews, Kizzie, Rowley, 
\& Cortina, 2010). In the same domain, the beneficial effect of schooling on general intelligence is assumed, currently recognized as sensitivity to environmental influences (Najman et al., 2009; Nisbett et al., 2012). This progress, however, seems to be modulated by individual differences that tend to crystallize over time, as suggested by longitudinal studies performed with a focus on academic performance, between kindergarten education (KE) and the $1^{\text {st }}$ year (Cadima, McWilliam, \& Leal, 2010), between KE and the $2^{\text {nd }}$ year (Ding, Richardson, \& Schnell, 2013) and between the $3^{\text {rd }}$ and $5^{\text {th }}$ year of EE (Gardinal-Pizato et al., 2012). Gender is among the factors that contribute to differences in academic achievement, with indications of an advantage for girls during EE (Grimm, Steele, Mashburn, \& Pianta, 2010; Matthews et al., 2010).

In the psychosocial domain, the results of empirical studies are not as consistent, indicating different trajectories of development for social skills and behavioral adjustment indicators. For social skills (SS), on one hand there is evidence of expansion (Berry \& O'Connor, 2010; Chen \& French, 2008; Miner \& ClarkeStewart, 2008), while conversely, there are accounts of reduction, albeit modest (Reynolds, Sander, \& Irvin, 2010; Sallquist et al., 2009). Bolsoni-Silva, Marturano and Freiria (2010), based on teacher evaluations, found an increase in SS between KE and EE, in children who presented behavioral problems in $\mathrm{KE}$, however, a slight reduction in the children that were initially without behavioral problems.

Evidence of only moderate stability over time, found in more than one study (Pizato, Marturano, \& Fontaine, 2014; Stipek, Newton, \& Chudgar, 2010), suggests that there is no uniform pattern in the trajectory of SS development over the years of EE. In search of different trajectories for different classes of SS, Lamont and Van Horn (2013), using the parent version of the Social Skills Rating System (SSRS), detected discrete increases in the assertion, responsibility and self-control SS for the majority of the children, between 5 and 9 years of age, while the cooperation with peers SS did not change.

Behavioral adjustment is also expressed in different directions, depending on the type of manifestation evaluated. The reduction of externalizing manifestations as children advance in the years of EE seems well established (Fanti \& Henrich, 2010; Silver, Measelle, Armstrong, \& Essex, 2010; Robbers et al., 2010). In contrast, for internalizing behaviors, studies using the same class of informant - the teacher - and employing the same instrument - SSRS - have reported divergent results; there is both evidence of a slightly increasing trajectory, between kindergarten and the $5^{\text {th }}$ year of EE (Reynolds et al., 2010), as well as a declining trajectory between the $3^{\text {rd }}$ and $5^{\text {th }}$ years (Pizato et al., 2014). Based on the self-assessments of children, Wetter and ElSheikh (2012) detected declining trajectories from 8 to 10 years of age. Fanti and Henrich (2010), using maternal evaluations, found stable trajectories from 2 to 12 years for the majority $(82 \%)$ of the children monitored.

Regarding individual differences, gender appears to play an important role in the developmental trajectory of SS and behavioral problems throughout EE. Specifically, girls are seen by teachers as more socially skilled (Bandeira, Rocha, Freitas, Del Prette, \& Del Prette, 2006; Sallquist et al., 2009) and with fewer externalizing problems (Fanti \& Henrich, 2010; Robbers et al., 2010; Silver et al., 2010).

The studies reviewed in the preceding paragraphs relate to normative developmental achievements in the period of development from the last year of KE and the fifth year of EE. Summarizing the literature findings, the expansion of academic skills and the reduction of externalizing behaviors seem to be well established. For SS and internalizing behaviors the results are inconsistent or even conflicting. Although the diversity of findings can be partly explained by methodological differences, such as the choice of informants - mothers, teachers, or children themselves - there are significant gaps, requiring further investigation. With respect to SS, the study of Lamont and Van Horn (2013) suggests that replacing the traditional overall approach with a focus on different classes of SS could be useful in identifying different trajectories of development. With respect to internalizing problems, replications would be important to clarify the apparently contradictory results.

\section{The Transition from the 1 st Year of EE}

To study the trajectory of development in the early years of EE, as well as possibly contributing to the elucidation of the points mentioned, presents an additional interest in that it coincides with an important school transition. Entering EE implies change (e.g., from one school to another), loss (e.g., separation from friends of the kindergarten school), pressure (e.g., for performance), unpredictability (e.g., changing the routine) and uncontrollability (e.g., not knowing the rules in the new context). This combination can make children particularly vulnerable to stress at the beginning of EE. A cross-sectional study with students from the 
$1^{\text {st }}$ to $4^{\text {th }}$ grades of the former EE system of eight years showed that the children of the $1^{\text {st }}$ grade presented more stress symptoms and that the presence of stress decreased in the higher grades (Lipp, Arantes, Buriti, \& Witzig, 2002).

Results consistent with the notion of school transition were also detected in a prospective study in the $1^{\text {st }}$ grade of EE, in which the students reported, at the end of the year, their stress symptoms and perception of school stressors. In the results, the children without previous access to kindergarten education presented more symptoms and more stressor events, showing a transition effect modulated by the previous school experience of the children (Trivellato-Ferreira \& Marturano, 2008).

These results require verification for two reasons. The first, most obvious, refers to the theoretical and practical importance of any possible empirical evidence that suggests that the entry into the EE could be associated with an increased risk of symptoms and stress experiences. The second reason is related to the change that occurred with the deployment of the EE system of nine years, instituted by the Lei de Diretrizes e Bases da Educaşão Nacional (LDB 9394/96) and made compulsory throughout the country from 2010. With EE of nine years, children enter this level of education one year younger. The average age of children in the $1^{\text {st }}$ year is approximately six years, not seven as in the old $1^{\text {st }}$ grade. This age difference alone, given the developmental implications, justifies the performance of a longitudinal study with a view to replicating the age trend associated with the stress symptoms reported by Lipp et al. (2002), as well as the measure of perceived school stressors introduced by Trivellato-Ferreira and Marturano (2008).

In this article, aspects of development in the cognitive and psychosocial domains are examined from the $1^{\text {st }}$ year, which marks the transition between $\mathrm{KE}$ and EE. To represent skills in the cognitive domain, general intelligence and school performance indicators are investigated. In the psychosocial domain, indicators of SS and behavioral adjustment, expressed as internalizing and externalizing behavior, are investigated. To capture possible processes arising from the transition, stress indicators are aggregated. The aims were: to verify the evolution of academic performance indicators, general intelligence, SS, behavioral problems, stress symptoms and perception of school stressors during the $1^{\text {st }}, 2^{\text {nd }}$ and $3^{\text {rd }}$ years of EE considering stability and changes in these variables, and whether there was an effect of the gender of the child on the variation over the three years.

Based on the literature reviewed, some hypotheses were raised: (1) the indicators of academic performance and general intelligence would have increasing trajectories, with high stability in the individual differences; (2) externalizing behavioral problems would have a declining trajectory and high stability; (3) stress symptoms would have a declining trajectory, once the $1^{\text {st }}$ year transition was passed. No result was anticipated for the other variables investigated - SS, internalizing problems and perception of school stressors - due to a lack of empirical support.

\section{Method}

\section{Ethical Considerations}

This study is part of a project approved by the Research Ethics Committee. It adheres to the standards and guidelines laid out in Resolution No. 196/96 of CONEP, and the provisions of Resolution No. 016/2000 of the Federal Council of Psychology. Before starting the data collection, the adult participants signed the Informed Consent (IC) form; in the case of a child participant, the person responsible signed the IC form and the participant gave prior verbal consent.

\section{Participants}

The convenience sample consisted of children who participated in the three stages of evaluation of a larger study (Correia-Zanini, 2013). Thus, 151 of the 186 children recruited in the original study participated ( $81 \%$ of the initial sample), 79 boys and 72 girls, with initial age of 5 years and 8 months to 7 years and 6 months (mean 6 years and 8 months), with 25 teachers of the $1^{\text {st }}$ year, 30 teachers of the $2^{\text {nd }}$ year and 33 teachers of the $3^{\text {rd }}$ year. The children attended EE of nine years in municipal public schools.

\section{Location}

The study took place in seven public schools in a city, of approximately 111,000 inhabitants, in São Paulo state. In 2010, the year of the beginning of data collection, the municipal school system had 59 classes of the $1^{\text {st }}$ year, distributed in fifteen schools. The selection of schools was carried out with support from the municipal education department, aiming to represent different regions, with a school in the central region, two near the center and four in outer neighborhoods, totaling 25 classes. 
Instruments and Measures

Social Skills Rating System (SSRS-BR) Teachers Version (Bandeira, Del Prette, Del Prette, \& Magalhães, 2009). This is comprised of three scales: SS, organized into five subscales (cooperation with peers, positive assertion, responsibility/cooperation, self-defense and self-control); Academic Competence; and Behavioral Problems, organized into two subscales (internalizing and externalizing). For each item the teacher records the frequency with which the pupil presents certain SS and behavioral problems, never (0 point), sometimes ( 1 point) or always ( 2 points). For academic competence, the teacher should record, on a scale of zero to five, his/her judgment regarding the learning and academic performance of the student in relation to the classmates. In this study, the SS and behavioral problems scales were used, with the composition of items defined by confirmatory factor analysis on the sample of the original study (CorreiaZanini, 2013).

Raven's Colored Progressive Matrices Special Scale, Note Book Form (Angelini, Alves, Custódio, Duarte, \& Duarte, 1999). Standardized for the Brazilian population, aims to assess the intellectual level of children of 5 to 11 and a half years of age. The test consists of three scales $(\mathrm{A}, \mathrm{AB}$ and $\mathrm{B})$, each with twelve figures. Each figure is presented on one page, and the subject must choose, among six alternatives printed on the same page, the one that would logically complete the presented figure. Every correct response scores one point, with a maximum raw score of 36 points. The raw scores are converted into percentiles, which form the basis for the classification of "intellectually deficient", "below average intellectual capacity", "intellectually average", "above average intellectual capacity" or "intellectually superior". In this work the raw scores were used.

Provinha Brazil 2009 (Brazil, 2009). This is an evaluation prepared by the Anísio Teixeira National Institute of Educational Studies and Research - INEP and aims to diagnose the literacy level of children enrolled in the $2^{\text {nd }}$ year of EE. It consists of an example question to teach students how they should respond to the test and another 24 multiple-choice questions to assess performance. The performance evaluation questions are arranged in order of increasing demand for skills, from the most basic to the most advanced. Each correctly answered question corresponds to one point. In this study, the test was expanded with appropriate questions for $3^{\text {rd }}$ year students (Correia-Zanini, 2013).
Childhood Stress Scale - CSS (Lipp \& Lucarelli, 2008). This scale aims to identify how often children of six to 14 years of age experience stress symptoms and at what phase they are in (without stress, alert phase, resistance phase, almost exhaustion phase or exhaustion). It is composed of 35 Likert items, which are grouped into four factors: physical reactions, psychological reactions, psychological reactions with depressive component, and psycho-physiological reactions. For each item the child should paint one to four quadrants of a circle indicating how often the particular symptom occurs (never happens - no quadrant, a little - one quadrant, sometimes - two quadrants, almost always - three quadrants; always - four quadrants). For this study we used the total raw value.

School Stressors Inventory - SSI (TrivellatoFerreira \& Marturano, 2008). The inventory investigates everyday tensions related to school life in four domains: school performance, family-school relationship, relationship with peers, and other demands of school life. For each situation presented, the child responds as to whether it happened to him/her during the academic year; if the event happened one point is assigned. The child also reports how much the situation bothered him/her - not at all (0 points), slightly (1 point) somewhat ( 2 points) or a lot ( 3 points). In this study the two-component structure - Tensions Related to the Student Role and Interpersonal Relations - was used, determined by exploratory factor analysis on the $1^{\text {st }}$ year sample, and confirmatory on the $2^{\text {nd }}$ and $3^{\text {rd }}$ year samples (Correia-Zanini, 2013).

Procedure

The data collection with the children and teachers took place in November and December 2010, and from September to December 2011 and 2012, in class time and in places arranged by the schools. The children individually answered the SSI, CSS and Raven's Colored Progressive Matrices instruments. The Provinha Brazil was applied collectively by the first author with the help of an assistant. The teachers were given guidance about completing the forms of the SSRS, in Collective Pedagogical Work Time - CPWT. An e-mail address and telephone number was made available to clarify any doubts and a deadline for returning the completed forms was agreed.

Data were analyzed using SPSS - version 19. To assess the stability of the variables over the three years, Pearson correlation test was applied. The mixed ANOVA for repeated measures was performed to 
detect temporal variations, taking into account gender, preceded by verification of its assumptions (Marôco, 2011). These were attended to, except for the academic performance, general intelligence, self-defense and responsibility/cooperation variables, for which the sphericity test indicated violation of the homogeneity of variances assumption. In these cases, the F-test was used to measure the significance of temporal variations that was provided by MANOVA on the data set and not given by the ANOVA for repeated measures (Marôco, 2011).

For the multiple comparison of the means in the three moments the Bonferroni post-hoc test was used. When a significant effect of interaction between gender and time was detected, ANOVA for repeated measures was performed for both genders, in order to find the variations for boys and girls over time. Student $t$-test was used to compare the mean obtained by the boys and girls in each year.

\section{Results}

The correlations between the variables throughout the years are presented in Table 1. All were significant and positive, that is, if the child occupied a determined position in the sample in the $1^{\text {st }}$ year, this position tended to be maintained in the subsequent year, suggesting stability of the variables. The majority of the coefficients obtained were classified as moderate, according to Hair, Black, Babin, Anderson and Tatham (2009) who classified correlations as weak when they present values less than 0.30 , as moderate between 0.30 and 0.69 , and strong above 0.70 . Strong correlations can be observed in the Provinha Brazil, between the $1^{\text {st }}$ and the $2^{\text {nd }}$ year, and also between the $2^{\text {nd }}$ and $3^{\text {rd }}$ year. The same was the case for externalizing behavioral problems in the $2^{\text {nd }}$ and $3^{\text {rd }}$ years. Weak correlations were observed for cooperation with peers between the $1^{\text {st }}$ and $2^{\text {nd }}$ year, as well as for internalizing behavioral problems and for tensions in interpersonal relationships between the $1^{\text {st }}$ and $3^{\text {rd }}$ year.

The mixed ANOVA for repeated measures was applied to investigate the effect of time $\left(1^{\text {st }}, 2^{\text {nd }}\right.$ and $3^{\text {rd }}$ years of $\mathrm{EE})$, of gender and of the interaction between time and gender on the dependent variables: academic performance, general intelligence, SS, behavioral problems, and stress. The means of the sample and the differences observed from the post hoc test are shown in Table 2. The means obtained for girls and boys are presented in Table 3, as well as the indication of gender differences found in the $1^{\text {st }}$, the $2^{\text {nd }}$ and $3^{\text {rd }}$ years, identified with Student $t$-test. The results presented in Tables 2 and 3 are described together for each dependent variable.

Table 1

Correlations between Variables of the Child in the $1^{\text {st }}, 2^{\text {nd }}$ and $3^{\text {rd }}$ Years

\begin{tabular}{llll}
\hline Variables & $1^{\text {st }}-2^{\text {nd }}$ & $2^{\text {nd }}-3^{\text {rd }}$ & $1^{\text {st }}-3^{\text {rd }}$ \\
\hline Academic performance & $0.70^{*}$ & $0.75^{*}$ & $0.61^{*}$ \\
General intelligence & $0.65^{*}$ & $0.49^{*}$ & $0.45^{*}$ \\
Self-control & $0.41^{*}$ & $0.45^{*}$ & $0.41^{*}$ \\
Positive assertion & $0.41^{*}$ & $0.41^{*}$ & $0.42^{*}$ \\
Self-defense & $0.55^{*}$ & $0.35^{*}$ & $0.34^{*}$ \\
Responsibility and cooperation & $0.60^{*}$ & $0.60^{*}$ & $0.55^{*}$ \\
Cooperation with peers & $0.27^{*}$ & $0.43^{*}$ & $0.31^{*}$ \\
Externalizing behavior & $0.48^{*}$ & $0.72^{*}$ & $0.59^{*}$ \\
Internalizing behavior & $0.33^{*}$ & $0.40^{*}$ & $0.25^{*}$ \\
Stress symptoms & $0.46^{*}$ & $0.60^{*}$ & $0.47^{*}$ \\
Tensions related to the student role & $0.44^{*}$ & $0.41^{*}$ & $0.33^{*}$ \\
Tensions in interpersonal relationships & $0.38^{*}$ & $0.39^{*}$ & $0.29^{*}$ \\
\hline
\end{tabular}

Note. $N=151 .{ }^{*} p<0.001$ 
To assess the magnitude of the differences, the effect was considered small when $\eta_{\mathrm{p}}^{2} \leq 0.05$ and $d$ was $\leq 0.2$; moderate when the $\eta_{\mathrm{p}}^{2}$ varied from 0.051 to 0.25 and $d$ was between 0.2 and 0.5 ; large when $\eta_{p}^{2}$ was between 0.26 and 0.50 and $d$ was between 0.50 and 1 ; very large when $\eta_{\mathrm{p}}^{2}>0.50$ and $d$ was $>1$ (Cohen, 1992; Marôco, 2011).

Time had a positive significant effect on academic performance, with large magnitude of effect [Pillai's criterion $=0.85, F(2,148)=411.074, p<$ $\left.0.001, \eta_{\mathrm{p}}^{2}=0.847\right]$; according to the post hoc test, the means increased from year to year. Gender also had an effect, however of small magnitude $[F(1,149)=$ 14.777, $\left.p<0.001, \eta_{\mathrm{p}}^{2}=0.090\right]$. The results of Student $t$-test showed that the girls in the three years presented better mean performance than the boys $\left[t_{1 \mathrm{st} \mathrm{year}}(149)\right.$ $=-3.501, p=0.001 ; d=0.57 ; t_{2 \text { nd year }}(149)=-3.573, p$ $<0.001, d=0.53 ; t_{3 \text { rd year }}(149)=-3.060, p=0.003, d=$ 0.24 , with a large effect size for the $1^{\text {st }}$ and $2^{\text {nd }}$ years and moderate effect size for the $3^{\text {rd }}$ year. There was no significant effect of interaction between time and gender [Pillai's criterion $=0.004, F(2,148)=0.330, p$ $\left.=0.719, \eta_{\mathrm{p}}^{2}=0.004\right]$.

Time had a positive significant effect for general intelligence, with a large effect size [Pillai's criterion $=0.27, F(2,148)=27.014, p<0.001, \eta_{\mathrm{p}}^{2}=0.267$; according to the post hoc test, there was a significant mean increase in the $3^{\text {rd }}$ year in relation to the $1^{\text {st }}$ and $2^{\text {nd }}$ years. There was no effect of gender $[F(1,149)=$ $\left.0.030, p>0.05, \eta_{\mathrm{p}}^{2}=0.000\right]$, or of time-gender interaction [Pillai's criterion $=0.010, F(2,148)=0.720, p=$ 0.489, $\left.\eta_{\mathrm{p}}^{2}=0.010\right]$.

ANOVA detected no effect of time for the selfcontrol social skill $\left[F(2,298)=0.510, p=601, \eta_{p}^{2}=\right.$ 0.003]. Gender showed a significant effect of moderate magnitude $\left[F(1,149)=17.093, p<0.001, \eta_{p}^{2}=0.103\right]$; the girls presented higher means in the three years $\left[t_{1 \mathrm{st}}\right.$ year $(149)=-2.320, p=0.022, d=0.33 ; t_{2 \text { nd year }}(149)=$ $-2.901, p=0.004, d=0.53 ; t_{3 \text { rd year }}(149)=-4.245, p<$ $0.001, d=0.69]$. The effect was moderate for the $1^{\text {st }}$ year and large for the $2^{\text {nd }}$ and $3^{\text {rd }}$ years. There was no effect of interaction between time and gender $[F(2$, 298) $\left.=2.142, p=0.119, \eta_{\mathrm{p}}^{2}=0.014\right]$.

For positive assertion, according to ANOVA, time presented a significant effect of small magnitude $[F(2$, 298) $\left.=6.193 p=0.002, \eta_{\mathrm{p}}^{2}=0.040\right]$. According to the post hoc test, the mean in the $2^{\text {nd }}$ year was lower than in the $1^{\text {st }}(p=0.018)$ and $3^{\text {rd }}$ years $(p=0.007)$. Gender also had a significant effect of moderate magnitude $[F$ $\left.(1,149)=18.082, p=0.000, \eta_{p}^{2}=0.108\right]$. The girls presented a higher mean than the boys in the three grades $\left[t_{1 \text { st year }}(149)=-2.956, p=0.004, d=0.48 ; t_{2 \text { nd year }}(149)\right.$ $=-3.549, p=0.001, d=0.58 ; t_{3 \text { rd year }}(149)=-3.192, p=$ $0.002, d=0.53$, with a moderate effect size in the $1^{\text {st }}$

Table 2

Differences between Means for the Variables of the Child in the $1^{\text {st }}$, the $2^{\text {nd }}$ and $3^{\text {rd }}$ Years

\begin{tabular}{lccc}
\hline \multirow{2}{*}{ Variables } & \multicolumn{3}{c}{ Total sample - Mean $(S D)$} \\
\cline { 2 - 4 } & $1^{\text {st }}$ year & $2^{\text {nd }}$ year & $3^{\text {rd }}$ year \\
\hline Academic performance & $13.11^{\mathrm{a}}(4.80)$ & $18.35^{\mathrm{b}}(4.53)$ & $22.73^{\mathrm{c}}(4.46)$ \\
General intelligence & $18.28^{\mathrm{a}}(4.11)$ & $18.90^{\mathrm{a}}(4.86)$ & $21.27^{\mathrm{b}}(5.16)$ \\
Self-control & $10.19^{\mathrm{a}}(3.22)$ & $10.49^{\mathrm{a}}(3.55)$ & $10.33^{\mathrm{a}}(3.73)$ \\
Positive assertion & $8.75^{\mathrm{b}}(2.92)$ & $7.95^{\mathrm{a}}(3.47)$ & $8.86^{\mathrm{b}}(3.10)$ \\
Self-defense & $3.05^{\mathrm{a}}(1.59)$ & $2.91^{\mathrm{a}}(1.86)$ & $2.95^{\mathrm{a}}(1.68)$ \\
Responsibility and cooperation & $9.97^{\mathrm{ab}}(3.37)$ & $9.45^{\mathrm{a}}(3.78)$ & $10.10^{\mathrm{b}}(3.48)$ \\
Cooperation with peers & $3.52^{\mathrm{b}}(1.72)$ & $3.03^{\mathrm{a}}(1.81)$ & $3.58^{\mathrm{b}}(1.61)$ \\
Externalizing behavior & $4.81^{\mathrm{b}}(3.42)$ & $4.20^{\mathrm{a}}(3.72)$ & $4.47^{\mathrm{ab}}(3.86)$ \\
Internalizing behavior & $2.91^{\mathrm{b}}(2.26)$ & $2.35^{\mathrm{a}}(2.24)$ & $2.54^{\mathrm{ab}}(2.41)$ \\
Stress symptoms & $48.25^{\mathrm{b}}(23.51)$ & $53.64^{\mathrm{c}}(22.07)$ & $40.99^{\mathrm{a}}(21.86)$ \\
Tensions related to the student role & $12.44^{\mathrm{a}}(7.70)$ & $12.21^{\mathrm{a}}(7.22)$ & $11.76^{\mathrm{a}}(6.97)$ \\
Tensions in interpersonal relationships & $8.61^{\mathrm{a}}(6.68)$ & $9.19^{\mathrm{a}}(6.39)$ & $9.41^{\mathrm{a}}(6.12)$ \\
\hline
\end{tabular}

Note. Different letters indicate significantly different means in the mixed ANOVA for repeated measures. SD = standard deviation 
Table 3

Differences between Means of Boys and Girls in the $1^{\text {st }}$, the $2^{\text {nd }}$ and $3^{\text {rd }}$ Years

\begin{tabular}{|c|c|c|c|c|c|c|}
\hline \multirow[t]{2}{*}{ Variables } & \multicolumn{2}{|c|}{$\begin{array}{c}1^{\text {st }} \text { year } \\
\text { Mean }(S D)\end{array}$} & \multicolumn{2}{|c|}{$\begin{array}{c}2^{\text {nd }} \text { year } \\
\text { Mean }(S D)\end{array}$} & \multicolumn{2}{|c|}{$\begin{array}{c}3^{\text {rd }} \text { year } \\
\text { Mean }(S D)\end{array}$} \\
\hline & Girls & Boys & Girls & Boys & Girls & Boys \\
\hline $\begin{array}{l}\text { Academic } \\
\text { performance } a b c\end{array}$ & $14.49(4.66)$ & $11.85(4.59)$ & $19.68(4.91)$ & $17.14(4.74)$ & $23.86(4.08)$ & $21.70(4.57)$ \\
\hline General intelligence & $18.32(3.75)$ & $18.76(5.17)$ & $19.06(4.53)$ & $18.25(4.43)$ & $20.90(5.43)$ & $21.59(4.91)$ \\
\hline Self-control ${ }^{\mathrm{abc}}$ & $10.82(2.82)$ & $9.71(3.78)$ & $11.35(3.09)$ & $9.62(3.47)$ & $11.61(3.40)$ & $9.16(3.65)$ \\
\hline Positive assertion $\mathrm{abc}^{\mathrm{b} c}$ & $9.47(2.60)$ & $8.10(3.05)$ & $8.96(2.83)$ & $7.03(3.75)$ & $9.68(2.77)$ & $8.11(3.22)$ \\
\hline Self-defense ${ }^{a b}$ & $3.35(1.49)$ & $2.53(1.87)$ & $3.33(1.77)$ & $2.78(1.63)$ & $3.17(1.73)$ & $2.75(1.61)$ \\
\hline $\begin{array}{l}\text { Responsibility and } \\
\text { cooperation }^{\mathrm{abc}}\end{array}$ & $10.96(2.72)$ & $9.08(3.65)$ & $10.92(3.11)$ & $8.11(3.85)$ & $11.39(2.87)$ & $8.92(3.58)$ \\
\hline $\begin{array}{l}\text { Cooperation with } \\
\text { peers }^{\mathrm{abc}}\end{array}$ & $4.03(1.53)$ & $3.05(1.75)$ & $3.57(1.53)$ & $2.54(1.92)$ & $4.06(1.40)$ & $3.14(1.68)$ \\
\hline $\begin{array}{l}\text { Externalizing } \\
\text { behavior }^{\mathrm{a}} \mathrm{c}\end{array}$ & $4.08(3.25)$ & $5.20(4.02)$ & $3.10(3.01)$ & $5.47(3.45)$ & $3.01(3.09)$ & $5.80(4.02)$ \\
\hline $\begin{array}{l}\text { Internalizing } \\
\text { behavior }^{\mathrm{b}}\end{array}$ & $2.75(2.30)$ & $3.06(2.23)$ & $1.89(1.98)$ & $2.77(2.39)$ & $2.24(2.33)$ & $2.81(2.46)$ \\
\hline Stress symptoms & $46.08(20.76)$ & $50.23(25.28)$ & $55.85(23.84)$ & $51.63(20.28)$ & $42.33(23.38)$ & $39.77(20.46)$ \\
\hline $\begin{array}{l}\text { Tensions related to } \\
\text { the student role }\end{array}$ & $11.51(7.67)$ & $13.29(7.68)$ & $11.50(7.13)$ & $12.8(7.29)$ & $12.08(7.35)$ & $11.47(6.65)$ \\
\hline $\begin{array}{l}\text { Tensions in } \\
\text { interpersonal } \\
\text { relationships }\end{array}$ & $9.14(6.52)$ & $8.14(6.83)$ & $8.92(5.74)$ & $9.43(6.96)$ & $9.86(6.17)$ & $9.00(6.09)$ \\
\hline
\end{tabular}

Note. $S D=$ Standard Deviation. ${ }^{a}=$ significantly different means in Student $t$-test in the $1^{\text {st }}$ year; ${ }^{\mathrm{b}}=$ significantly different means in Student $t$-test in the $2^{\text {nd }}$ year ${ }^{c}{ }^{c}=$ significantly different means in Student $t$-test in the $3^{\text {rd }}$ year .

year and large effect size in the other years. There was no effect of interaction between time and gender $[F(2$, 298) $\left.=0.517, p=0.597, \eta_{\mathrm{p}}^{2}=0.003\right]$.

The result of the MANOVA for self-defense showed no main effect of time [Pillai's criterion $=$ $\left.0.008, F(2,148)=0.563, p=0.571, \eta_{\mathrm{p}}^{2}=0.008\right]$ and of time-gender interaction [Pillai's criterion $=0.010, F(2$, $\left.148)=0.733, p=0.482, \eta_{\mathrm{p}}^{2}=0.010\right]$. A small magnitude effect was observed for gender $[F(1,149)=7.841$, $\left.p<0.05, \eta_{\mathrm{p}}^{2}=0.050\right]$; in the year to year comparisons, the girls had higher means in the $1^{\text {st }}$ and $2^{\text {nd }}$ year, with a moderate effect size $\left[t_{1 \text { st year }}(149)=-2.203, p=0.029, d\right.$ $=0.49 ; t_{\text {2nd year }}(149)=-2.703, p=0.008, d=0.32 ; t_{3 \text { rd year }}$ $(149)=-1.544, p=0.125, d=0.25]$.

The main effect of time was significant for responsibility and cooperation, being of small magnitude
[Pillai's criterion $=0.042, F(2,148)=3.228, p=0.042$, $\left.\eta_{\mathrm{p}}^{2}=0.042\right]$, however, the post hoc analysis only indicated a trend $(p=0.052)$ of higher mean in the $3^{\text {rd }}$ year compared to the $2^{\text {nd }}$ year. Gender had a main effect of moderate magnitude $\left[F(1,149)=27.879, p<0.001, \eta_{\mathrm{p}}^{2}\right.$ $=0.158]$. Girls had higher means and the effect size was large in the three moments $\left[t_{1 \mathrm{st} \mathrm{vear}}(149)=-3.611\right.$, $p<.001, d=0.58 ; t_{\text {2nd year }}(149)=-4.939, p<0.001, d=$ $\left.0.80 ; t_{3 \text { rd year }}(149)=-4.683, p<0.001, d=0.76\right]$. There was no effect of interaction between time and gender $\left[F(2,298)=1.554, p=0.215, \eta_{\mathrm{p}}^{2}=0.021\right]$.

There was a main effect of time on the means of cooperation with peers, with a small effect size $[F(2$, 298) $\left.=6.726 ; p=0.001, \eta_{\mathrm{p}}^{2}=0.043\right]$; according to the post hoc analysis, the mean was significantly lower in the $2^{\text {nd }}$ year, in comparison with $1^{\text {st }}$ and $3^{\text {rd }}$ year. There 
was also a moderate magnitude effect of gender $[F(1$, $\left.149)=25.273, p<0.001, \eta_{p}^{2}=0.145\right]$. The girls had higher means in the three years, with large effect size $\left[t_{1 \text { st year }}(149)=-3.634, p<0.001, d=0.60 ; t_{2 \text { nd year }}(149)\right.$ $=-3.607, p<0.001, d=0.59 ; t_{3 \text { rd year }}(149)=-3.622, p$ $<0.001, d=0.59$. There was no effect of interaction between time and gender $[F(2,298)=0.057, p=0.945$, $\left.\eta_{\mathrm{p}}^{2}=0.000\right]$.

Regarding externalization, the mixed ANOVA for repeated measures indicated a main effect of time, of small magnitude $\left[F(2,248)=3.216, p=0.042, \eta_{\mathrm{p}}^{2}=\right.$ 0.021]. According to the post hoc test, the children had higher means in the $1^{\text {st }}$ year than in the $2^{\text {nd }}$ year. The effect of gender was significant and of large magnitude $\left[F(1,149)=17.792, p<0.001, \eta_{p}^{2}=0.107\right]$. Boys presented more externalizing behavioral problems, with a moderate effect size in the $1^{\text {st }}$ year and large in the $2^{\text {nd }}$ and $3^{\text {rd }}$ years $\left[t_{1 \text { st vear }}(149)=2.531, p=0.012, d=\right.$ $0.31 ; t_{2 \text { nd year }}(149)=3.663, p<0.001, d=0.73 ; t_{3 \text { rd year }}$ $(149)=4.795, p<0.001, d=0.79]$. There was a small effect of interaction between time and gender $[F(2$, 298) $\left.=3.970 ; p=0.004 ; \eta_{\mathrm{p}}^{2}=0.026\right]$. The ANOVA for repeated measures processed separately by gender showed that the girls significantly reduced externalizing behaviors between the $1^{\text {st }}$ and the $2^{\text {nd }}$ years $[F(2,142)$ $\left.=6.365, p=0.002, \eta_{\mathrm{p}}^{2}=0.082\right]$, with a moderate effect size, whereas the boys showed no variation over time $[F$ $\left.(2,156)=1.344 ; p=0.264, \eta_{\mathrm{p}}^{2}=0.017\right]$.

For internalizing problems a small effect of time was observed $\left[F(2,298)=3.629 ; p=0.028, \eta_{\mathrm{p}}^{2}=\right.$ 0.024]; the $1^{\text {st }}$ year presented a higher mean compared to the $2^{\text {nd }}$ year $(p=0.022)$, according to the post hoc analyses. There was an effect of gender, of small magnitude $\left[F(1,149)=4.582, p<0.05, \eta_{p}^{2}=0.030\right]$. Boys presented more internalizing problems in the $2^{\text {nd }}$ year, with a moderate effect size $\left[t_{1 \text { st vear }}(149)=0.849, p=\right.$ $0.397, d=0.14 ; t_{2 \text { nd year }}(149)=2.482, p=0.014, d=0.40$; $\left.t_{3 \text { rd year }}(149)=1.469, p=0.144, d=0.24\right]$. There was no effect of interaction between time and gender $[F(2$, 298) $\left.=0.859, \mathrm{p}=0.425, \eta_{\mathrm{p}}^{2}=0.006\right]$.

Time showed a moderate magnitude of effect on stress symptoms $\left[F(2,298)=24.951 ; p<0.001, \eta_{\mathrm{p}}^{2}=\right.$ $0.143]$. Of the three moments compared, the $2^{\text {nd }}$ year had the highest mean $(p=0.012)$ and the $3^{\text {rd }}$ year the lowest $(p=0.001)$. The was no effect of gender [F (1, $\left.149)=0.085, p>0.05, \eta_{\mathrm{p}}^{2}=0.001\right]$. There was a significant effect of interaction between time and gender, with an moderate magnitude $[F(2,298)=3.023$; $p=$ $\left.0.050, \eta_{\mathrm{p}}^{2}=0.020\right]$. In the analyses of repeated measures by gender, the girls presented a peak of stress symptoms in the $2^{\text {nd }}$ year $[F(2,142)=16.178 ; p<0.001$, $\left.\eta_{\mathrm{p}}^{2}=0.186\right]$, which was significantly different in relation to the $1^{\text {st }}$ and $3^{\text {rd }}$ years; the boys showed a reduction of symptoms in the $3^{\text {rd }}$ year compared to the $1^{\text {st }}$ and $2^{\text {nd }}$ years $\left[F(2,156)=12.321 ; p<0.001, \eta_{p}^{2}=0.136\right]$. In both comparisons moderate effect sizes were obtained.

For the tensions related to the student role, there was no main effect of time $[F(2,298)=0.472 ; p=$ $\left.0.624, \eta_{\mathrm{p}}^{2}=0.003\right]$ or gender $[F(1,149)=0.828, p>$ $\left.0.05, \eta_{\mathrm{p}}^{2}=0.006\right]$. There was also no effect of interaction between time and gender $[F(2,298)=1.907, p$ $\left.=0.150, \eta_{\mathrm{p}}^{2}=0.013\right]$. Regarding the tensions in interpersonal relationships there was also no main effect of time $\left[F(2,298)=0.926 ; p=0.397, \eta_{\mathrm{p}}^{2}=0.006\right]$, or gender $\left[F(1,149)=0.325 p>0.05, \eta_{\mathrm{p}}^{2} \stackrel{\mathrm{p}}{=} 0.002\right]$, or of interaction between time and gender $[F(2,298)=0.994$; $\left.p=0.371, \eta_{\mathrm{p}}^{2}=0.007\right]$.

\section{Discussion}

This study aimed to verify the evolution of indicators of academic performance, general intelligence, SS, behavioral problems, stress symptoms and perception of school stressors during the $1^{\text {st }}, 2^{\text {nd }}$ and $3^{\text {rd }}$ years of EE, considering stability and changes, as well as variations associated with gender. The results partially confirmed two of the three hypotheses.

The hypothesis that the academic performance and general intelligence indicators would have increasing trajectories, with high stability in the individual differences had some support. The results regarding gains over time were particularly robust, detected in the total sample and in both genders.

The measure of academic performance rose year by year, presenting high stability in consecutive years and the correlations between the consecutive years tended to increase. In the literature, high stability does not seem to be the norm for academic performance measures; recent studies have reported moderate correlations between evaluations made in the last year of $\mathrm{KE}$ and the first year of EE (Cadima et al., 2010), as well as throughout EE (Stipek et al., 2010). Conversely, there was support for the finding of the increasing correlation between consecutive years. Indications of a crystallization of the individual position of the children as typical or impaired in performance were found by Ding, Richardson and Schnell (2013) from the KE to the $2^{\text {nd }}$ year of EE. Similar results were reported by Gardinal-Pizato, Marturano and Fontaine (2012) between the $3^{\text {rd }}$ and $5^{\text {th }}$ years; in their study, the initial differences 
remained, even though the children presented progress. This seems to be the pattern in the sample of the present study, in which the children showed performance gains, maintaining, however, individual differences.

For general intelligence, a high correlation was found between the measures taken in the $1^{\text {st }}$ and $2^{\text {nd }}$ years, and a moderate correlation between the $2^{\text {nd }}$ and $3^{\text {rd }}$ years. As expected, there was an increasing trajectory. However, it was discernible only in the $3^{\text {rd }}$ year. This could indicate a cumulative effect of the experience in EE, so that a sufficiently long exposure could result in cognitive modification. Although causal relationship can not be inferred from correlations, the possibility of cumulative environmental influences on general intelligence has already been demonstrated, regarding both promotion and impairment (Najman et al., 2009; Nisbett et al., 2012).

The hypothesis that externalizing behavioral problems would have a declining trajectory and high stability was partially confirmed. An initial moderate correlation was observed, with the individual positions tending to stabilize over time (Pizato et al., 2014). However, there was no clear reduction of the externalizing problems, in agreement with other studies with the age group investigated (Fanti \& Henrich, 2010; Pizato et al., 2014; Robbers et al., 2010; Silver et al., 2010). Despite the initial decrease, between the $1^{\text {st }}$ and the $2^{\text {nd }}$ year, this was restricted to the female group and was not continued in the $3^{\text {rd }}$ year. It should be noted that the analysis performed captured only modal trends, without being able to detect different trajectories of externalization in the sample, as identified by Fanti and Henrich (2010).

The hypothesis that once the $1^{\text {st }}$ year transition was passed stress symptoms would have a declining trajectory was not confirmed. The report of stress symptoms was sensitive to the passage of time, however, instead of a reduction with the advancement of education (Lipp et al., 2002), an effect of interaction between time and gender was obtained. Among the girls there was a peak in the $2^{\text {nd }}$ year and a reduction in the $3^{\text {rd }}$ year, while among the boys the initial level was only attenuated in the $3^{\text {rd }}$ year. Seen from the school transition perspective, these results suggest a prolongation of the transition initiated in the $1^{\text {st }}$ year (Trivellato-Ferreira \& Marturano, 2008), rather than an easing of tensions with the familiarization of the child to the new context. Among the participants of the sample, students of the nine year EE system, it seems that this easing was only achieved in the $3^{\text {rd }}$ year. In support of this interpretation, it can be noted that the perception of everyday tensions at school did not show, over the years, any reduction suggestive of familiarization with the school environment; instead, the perceived stress indicators proved to be invariant over time, which suggests the maintenance of the initial levels of exposure to stressors in the school.

Given the inconsistency between results of previous studies, hypotheses were not formulated regarding stability and change in SS and internalizing problems. For internalizing problems, there was low stability and a clear trend of the results was not observed in relation to the passage of time. For SS, moderate correlations between consecutive measurements confirmed results from other studies (Pizato et al., 2014; Stipek et al., 2010). Regarding the course of development, the trajectories differed between the SS classes and, even when an effect of time was identified, this was of small magnitude.

Diversity in the results related to the course of development of the SS is present in the literature. Using the total score of SS from the parent version of the SSRS, Berry and O'Connor (2010) found positive acceleration in the trajectory of SS between kindergarten and the $5^{\text {th }}$ year. Other authors, using the teachers version of the SSRS, did not detect variation (Pizato et al., 2014) or even found a modest decrease between the $3^{\text {rd }}$ and $5^{\text {th }}$ years (Reynolds et al., (2010).

As outlined in relation to externalizing problems, the small effect size in the results of the time comparisons for SS and internalizing problems may be related to the analysis method used. The mixed ANOVA for repeated measures provides results of modal tendencies of the sample, which may mask a possible diversity of individual trajectories. For example, Bolsoni-Silva, Marturano and Freiria (2010) detected an increase in the sociability and initiative SS between 5 and 10 years of age, however, only in children who had behavioral problems in the first evaluation, while the children without indications of behavioral problems at age 5 showed a slight decrease in SS when evaluated by the EE teachers. For internalization, Fanti and Henrich (2010) identified different trajectories between 2 and 12 years of age, including an increasing trajectory up to 9 years, affecting $18 \%$ of the sample investigated.

Differences associated with gender were observed in various indicators, in agreement with previous findings, which conferred an advantage to girls in objective tests of academic performance (Grimm et al., 2010; Matthews et al., 2010) and social skills evaluated by the teacher (Bandeira et al., 2006; Sallquist et al., 2009). With the exception of the self-defense SS, 
with small effect size, the magnitude of the differences was at least moderate.

Gender differences in externalizing behavioral problems were also similar to those reported in other studies, indicating higher means among boys (Fanti \& Henrich, 2010; Robbers et al., 2010; Silver et al., 2010). In this case, the magnitude of the differences was in general large. In contrast, the magnitude of the differences was small for internalization, suggesting more problems among the boys. Considering the small size effect and the fact that consistent support for this result is not found in the recent literature, it should perhaps be disregarded, with the proviso that two previous Brazilian studies found similar results. One of them used the teacher version of the SSRS, with children from the $3^{\text {rd }}$ to $5^{\text {th }}$ years (Pizato et al., 2014); the other used the CBCL, an instrument for parents of children 4 to 17 years of age (Sá, Bordin, Martin, \& Paula, 2010).

Considering the results from the perspective of the passage of time, it appears that the $1^{\text {st }}$ year was the one in which the children showed lower academic performance and more emotional and behavioral problems. The $2^{\text {nd }}$ year stood out as the one in which the children reported more stress symptoms and were evaluated by their teachers with less positive assertion and less cooperation with peers. In the $3^{\text {rd }}$ year the children had the lowest levels of stress symptoms, the greatest cognitive potential and, in relation to the $2^{\text {nd }}$ year, more academic SS. In terms of stability of the individual differences, from both the academic and behavioral perspective, the individual positions tended to crystallize between the $2^{\text {nd }}$ and the $3^{\text {rd }}$ year. Thus, while the $2^{\text {nd }}$ year stands out as a critical phase in the process of adaptation to EE for the children, the $3^{\text {rd }}$ year appears to be the one in which achievements are consolidated and the transition overcome.

The study allowed the identification, in children of both genders, of changes in stress symptoms and psychosocial indicators, suggesting a process of adaptation to EE that would extend from the $1^{\text {st }}$ to the $3^{\text {rd }}$ year. If the stress reaction is situational, as postulated, then at the beginning of EE the children were chronically exposed to stressful situations, with a high cost in emotional distress. Thus, the implication of the results for educational practices is emphasized, with regard to the need to work with the transition, in order to minimize the stress that children experience. It would be for the school to implement measures of acceptance that favor a smoother transition.
The study has limitations that need to be mentioned. The convenience sample in a medium-sized municipality imposes limits for the generalization of the results. Another limitation was that the teacher acted as the sole evaluator of the psychosocial domain, when it is known that mothers would be in the best position to observe internalizing symptoms in their children (Fanti \& Henrich, 2010). The statistical analysis adopted did not allowed different developmental trajectories to be reconstituted, which would be possible by means of structural equation modeling in a numerically compatible sample.

The study can, therefore, be considered as an exploratory probe that opens up new investigation perspectives. Given the lack of studies that have investigated stress at the beginning of EE from a longitudinal perspective, there is a need to replicate the research to verify the results regarding stress. The impact of the transition in boys and girls is another issue to be investigated, because apparently the trajectory of the stress symptoms differs between the genders, however its intensity does not; in spite of the fact that the girls presented better academic performance and were evaluated as more competent in the psychosocial domain, they were not more protected from stress.

Other questions that remain open, requiring clarification, concern the developmental trajectory of the different classes of social skills and behavioral problems. One possibility to elucidate such results would be the inclusion, in the analysis, of variables related to the family and school contexts. Indicators of socioeconomic status, family environment resources and school quality, among others, may be considered in future investigations.

\section{References}

Angelini, A. L., Alves, I. C. B., Custódio, E. M., \& Duarte, W. F. (1999). Manual Matrizes Progressivas Coloridas. Escala Especial de J. c. Raven, Dr. John Raven e Dr. J. H. Court. Padronização brasileira. São Paulo: Casa do Psicólogo.

Bandeira, M., Del Prette, Z. A. P., Del Prette, A., \& Magalhães, T. (2009). Validação das escalas de habilidades sociais, comportamentos problemáticos e competência acadêmica (SSRS-BR) para o ensino fundamental. Psicologia: Teoria e Pesquisa, 25, 271282. doi: 10.1590/S0102-37722009000200016 
Bandeira, M., Rocha, S. S., Freitas, L. C., Del Prette, Z. A. P., \& Del Prette, A. (2006). Habilidades sociais e variáveis sociodemográficas em estudantes do ensino fundamental. Psicologia em Estudo, 11(3), 541549. doi: 10.1590/S1413-294X2006000200009

Berry, D., \& O'Connor, E. (2010). Behavioral risk, teacher-child relationships, and social skill development across middle childhood: A child-byenvironment analysis of change. Journal of Applied Developmental Psychology, 31(1), 1-14. doi: 10.1016/j. appdev.2009.05.001

Bolsoni-Silva, A. T., Marturano, E. M., \& Freiria, L. R. B. (2010). Indicativos de problemas de comportamento e de habilidades sociais em crianças: Um estudo longitudinal. Psicologia: Reflexão e Crítica, 23 (3), 506515. doi: 10.1590/S0102-79722010000300011

Brasil - INEP - Instituto Nacional de Estudos e Pesquisas Educacionais Anísio Teixeira (2009). Kit Teste $2^{\circ}$ semestre 2009. Retrieved from http://provinhabrasil.inep.gov.br, 2009. Acesso em 10 de março de 2010.

Cadima, J.; McWilliam, R. A., \& Leal, T. (2010). Environmental risk factors and children`s literacy skills during the transition to elementary school. Journal of Behavioral Development, 34(1), 24-33. doi: 10.1177/0165025409345045

Chen, X., \& French, D. C. (2008). Children's social competence in cultural context. Annual Review of Psychology, 59, 591-616. doi: 10.1146/annurev. psych.59.103006.093606

Cohen, J. (1992). A power primer. Psychological Bulletin, 112, 155-159. doi: 10.1037/0033-2909.112.1.155.

Correia-Zanini, M. R. G. (2013). Um estudo prospectivo sobre o percurso escolar de crianças nos primeiros anos do Ensino Fundamental (Tese de doutorado em Ciências). Curso de Pós-Graduação em Psicologia - Faculdade de Filosofia, Ciências e Letras de Ribeirão Preto da USP, Ribeirão Preto.

Ding, C., Richardson, L., \& Schnell, T. (2013). A developmental perspective on word literacy from kindergarten through the second grade. The Journal of Educational Research, 106(2), 132-145. doi: 10.1080/00220671.2012.667009

Fanti, K. A., \& Henrich, C. C. (2010). Trajectories of pure and co-occurring internalizing and externalizing problems from age 2 to age 12: Findings from the National Institute of Child Health and Human Development Study of Early Child Care. Developmental Psychology, 46(5), 1159-1175. doi: 10.1037/ a0020659

Gardinal-Pizato, E. C., Marturano, E., \& Fontaine, A. M. G. V. (2012). Acesso à educação infantil e trajetórias de desempenho escolar no ensino fundamental. Paidéia, 22(52), 187-196. doi: 10.1590/ S0103-863X2012000200005

Grimm, K. J., Steele, J. S., Mashburn, A. J., Burchinal, M., \& Pianta, R. C. (2010). Early behavioral associations of achievement trajectories. Developmental Psychology, 46, 976-983. doi: 10.1037/a0018878

Hair, J. F., Black, W. C., Babin, B. J., Anderson, R. E., \& Tatham, R. L. (2009). Análise Multivariada de dados ( $6^{\mathrm{a}}$ ed.). (A. S. Sant Anna, trad.) Porto Alegre: Bookman.

Lamont, A., \& Van Horn, M. L. (2013). Heterogeneity in parent-reported social skill development in early elementary school children. Social Development, 22(2), 384-405. doi: 10.1111/sode.12023

Lipp, M. E. N., Arantes, J. P., Buriti, M. S., \& Witzig, T. T. (2002). O estresse em escolares. Psicologia Escolar e Educacional.1(4), p. 51-56. doi: 10.1590/ S1413-85572002000100006

Lipp, M. E. N. \& Lucarelli, M. D. M. (2008). Escala de Stress Infantil (ESI): Manual. (Edição Revisada). São Paulo: Casa do Psicólogo, Papirus.

Marôco, J. (2011). Análise Estatística com o SPSS Statistics ( $5^{\mathrm{a}}$ ed.). Pero Pinheiro/Portugal: ReportNumber.

Matthews, J. S., Kizzie, K. T., Rowley, S. J., \& Cortina, K. (2010). African Americans and Boys: Understanding the literacy gap, tracing academic trajectories, and evaluating the role of learning-related skills. Journal of Educational Psychology, 102(3), p. 757-771. doi: 10.1037/a0019616

Miner, J. L., \& Clarke-Stewart, K. A. (2008). Trajectories of externalizing behavior from age 2 to age 9: Relations with gender, temperament, ethnicity, parenting, and rater. Developmental Psychology, 44, 771-786. doi: 10.1037/0012-1649.44.3.771

Najman, J. M., Fassa, M. R. H., Heron, M. A., Bor, W., O'Callaghan, M. J., \& Williams, G. M. (2009). The Impact of episodic and chronic poverty on child cognitive development. The Journal of Pediatrics, 154, 284-289. doi: 10.1016/j.jpeds.2008.08.052 
Nisbett, R. E., Aronson, J., Blair, C., Dickens, W., Flynn, J., Halpern, D. F., \& Turkheimer, E. (2012). Intelligence: New Findings and Theoretical Developments. American Psychologist,67(2), 130-159. doi: $10.1037 / \mathrm{a} 0026699$

Pizato, E. C. G., Marturano, E. M., \& Fontaine, A. M. G. V. (2014). Trajetórias de habilidades sociais e problemas de comportamento no ensino fundamental: Influência da educação infantil. Psicologia: Reflexão e Crítica, 27(1), 189-197. doi: 10.1590/ S0102-79722014000100021

Reynolds, M. R., Sander, J. B., \& Irvin, M. J. (2010). Latent curve modeling of internalizing behaviors and interpersonal skills through elementary school. School Psychology Quarterly, 25, 189-201. doi: $10.1037 /$ a0021543

Robbers, S. C. C., Bartels, M., van Oort, F. V. A., van Beijsterveldt, C. E. M., van der Ende, J., Verhulst, F. C., Boomsma, D. I., \& Huizink, A. C. (2010). A twin-singleton comparison of developmental trajectories of externalizing and internalizing problems in 6- to 12-Year-Old Children. Twin Research and Human Genetics, 13(1), 79-87. doi: 10.1375/ twin.13.1.79

Sá, D. G. F., Bordin, I. A. S., Martin, D., \& Paula, C. S. (2010). Fatores de risco para problemas de saúde mental na infância/adolescência. Psicologia: Teoria e Pesquisa, 26(4), p. 643-652. doi: 10.1590/ S0102-37722010000400008
Sallquist, J. V., Eisenberg, N., Spinrad, T. L., Reiser, M. Hofer, C., Zhou, Q., Liew, J., \& Eggun, N. (2009). Positive and negative emotionality: Trajectories across six years and relations with social competence. Emotion, 9, 15-28. doi: 10.1037/a0013970

Silver, R. B., Measelle, J. R., Armstrong, J. M., \& Essex, M. J. (2010). The impact of parents, child care providers, teachers, and peers on early externalizing trajectories. Journal of School Psychology, 48, 555-583. doi: 10.1016/j.jsp.2010.08.003

Stipek, D., Newton, S., \& Chudgar, A. (2010). Learning-related behaviors and literacy achievement in elementary school-aged children. Early Childhood Research Quarterly, 25, 385-395. doi: 10.1016/j. ecresq.2009.12.001

Trivellato-Ferreira, M. C., \& Marturano, E. M. (2008). Recursos da criança, da família e da escola predizem competência na transição da $1^{\mathrm{a}}$ série. Revista Interamericana de Psicologia, 42, 407-410. Retrieved from: http://www.psicorip.org/Resumos/PerP/ RIP/RIP041a5/RIP04254.pdf

Wetter, E. K., \& El-Sheikh, M. (2012). Trajectories of children's internalizing symptoms: the role of maternal internalizing symptoms, respiratory sinus arrhythmia and child sex. Journal of Child Psychology and Psychiatry, 53(2), 168-177. doi: 10.1111/j.1469-7610.2011.02470.x

Recebido em: 25/11/2014 Reformulado em: 07/05/2015 Aprovado: 14/08/2015 
Nota das autoras:

Apoio: CAPES; CNPq e FAPESP.

Sobre as autoras:

Marta Regina Gonçalves Correia-Zanini é psicóloga e mestre em Psicologia do Desenvolvimento e Aprendizagem pela UNESP de Bauru/SP, doutora em Ciências (Psicologia) pela USP de Ribeirão Preto, com estágio na Universidade do Porto-Portugal, e pós-doutora pela FMRP - USP, com bolsa Fapesp. Docente no UNIFAE, realiza pesquisas nas áreas de desenvolvimento e psicologia escolar e educacional.

E-mail:psico_marta@yahoo.com.br

Edna Maria Marturano é psicóloga, professora titular aposentada da Faculdade de Medicina de Ribeirão Preto-USP, orienta estudos de mestrado e doutorado no programa de pós-graduação em Psicologia da Faculdade de Filosofia, Ciências e Letras de Ribeirão Preto-USP e realiza investigações sobre o tema Socialização e desenvolvimento: subsídios para a prevenção de dificuldades adaptativas na escola.

E-mail: emmartur@fmrp.usp.br

Contato com as autoras:

Edna Maria Marturano

Rua Tenente Catão Roxo, 2650

CEP: 14051-140

Ribeirão Preto-SP, Brasil 
